\title{
Serum Selenium Concentration in Cervical Cancer Patients: Preliminary Study and Literature Review
}

\author{
Leri Septiani,, ${ }^{1,2}$ Yudi Mulyana Hidayat,, ${ }^{1,2}$ Mutakin,, ${ }^{2,3}$ Rizky Abdulah, ${ }^{2,3}$ Ahmad Faried, ${ }^{2}$ \\ Hiroshi Koyama ${ }^{4}$

\begin{abstract}
${ }^{1}$ Department of Obstetrics and Gynecology, Faculty of Medicine, Universitas Padjadjaran-Dr. Hasan Sadikin General Hospital, Bandung, Indonesia

${ }^{2}$ Oncology and Stem Cell Working Group, Health Research Unit, Faculty of Medicine, Universitas PadjadjaranDr. Hasan Sadikin General Hospital, Bandung, Indonesia ${ }^{3}$ Department of Pharmacology and Clinical Pharmacy, Faculty of Pharmacy, Universitas Padjadjaran, Bandung, Indonesia
\end{abstract} \\ ${ }^{4}$ Department of Public Health, Gunma University, Graduate School of Medicine, Maebashi, Gunma, Japan
}

\begin{abstract}
Objective: To analyze the role of selenium and glutathione peroxidase (GPx) in cervical cancer.

Methods: Serum selenium concentrations and GPx activities of 19 women with cervical cancer along with their healthy counterparts (control group) were obtained. Selenium concentration were measured fluorometrically and GPx activities were measured spectrophotometrically based on the quantity of NADPH used in the reduction of glutathione.

Results: The mean of serum selenium concentrations in cervical cancer group was significantly lower than that in the control group, $67.24 \pm 15 \mathrm{ng} / \mathrm{mL}$ and $77.05 \pm 12 \mathrm{ng} / \mathrm{mL}(\mathrm{p}=0.03)$, respectively. The mean GPx activity in the cervical cancer group was also significantly lower than that in the control group, $128.18 \pm 38 \Delta \mathrm{mmol} \mathrm{NADPH} / \mathrm{min} / \mathrm{L}$ and $148.9 \pm 23 \Delta \mathrm{mmol} \mathrm{NADPH} / \mathrm{min} / \mathrm{L}$ $(p=0.04)$, respectively. Multivariate analysis in the cervical cancer patients showed that the Fédération Internationale de Gynécologie et d'Obstétrique (FIGO) staging score (early vs. advanced) was inversely correlated with serum selenium concentration $(\mathrm{p}=0.027)$.
\end{abstract}

Conclusions: Serum selenium concentration and GPx activity was significantly

Received:

April 5, 2016 lower in the cervical cancer patients. Our results demonstrate that selenium and GPx activity may have an important role in the carcinogenesis of cervical cancer.

Revised: $\quad$ Keywords: Cervical cancer, glutathione peroxidase activity, selenium [IJIHS. 2016;4(2):56-61]

Accepted:

August 3, 2016

pISSN: 2302-1381; eISSN: 2338-4506; http://dx.doi.org/10.15850/ijihs.v4n2.833

\section{Introduction}

Cervical cancer is the second most common cancer in women worldwide. It is a preventable and a curable disease when identified at an early stage. It is widely accepted that specific human papillomaviruses (HPV) are the central etiologic agents of cervical carcinogenesis. However, there are also other environmental

\section{Correspondence:}

Leri Septiani, Department of Obstetrics and Gynecology,

Faculty of Medicine, Universitas Padjadjaran-Dr. Hasan

Sadikin General Hospital

Jl. Pasteur No. 38, Bandung, Indonesia

e-mail: lsfaried@gmail.com and host factors that play decisive roles in the persistence of HPV infection as well as further malignant conversion of cervical epithelium. ${ }^{1}$ It is well known that reactive oxygen species (ROS) play important roles in many pathological conditions including cancer. Under normal conditions their harmful effects upon the cells are neutralized to a large extent by cascades of antioxidant defense mechanisms. Over generation of ROS causes malfunction of antioxidant balance, and it is considered to be in a state of oxidative stress. ${ }^{2}$ During cancer development the generation of ROS interferes with organ functions directly by damaging proteins, fats and nucleotides. ${ }^{3}$ 
Selenium is one of the main components of antioxidative mechanisms with evidence that this essential trace element has anticancer properties. The increasing body of evidence suggests the protective role of selenium in several cancers including cervical cancer, ${ }^{4,5}$ Selenium exerts its chemopreventive effect in several ways, such as a defense against oxidative damage by scavenging the ROS, as well as improving the synthesis of enzymatic antioxidant glutathione peroxidase (GPX) ${ }^{6}$

The major physiological role of GPx is to maintain appropriate low levels of hydrogen peroxide within the cells and decrease the potential damages due to free radicals. It also provides a second line of defense against hydrogen peroxide that may create damage to membranes and deoxyribonucleate acid (DNA). ${ }^{6}$ It was also suggested that low serum selenium levels are linked to miscarriage; hence, selenium seems to play an important role in pregnancy maintenance. ${ }^{7}$

GPx activities and low serum concentrations of selenium have been linked to increased risk of many types of cancer including prostate, lung, colorectal, and bladder ${ }^{8-10}$ However, the role of selenium in preventing carcinogenesis of the cervical is still unclear. No study has explained the roles of selenium in cervical cancer. This study aimed to analyze the serum selenium concentrations and GPx activities in cervical cancer patients compared to the control group, as a preliminary study to explore the role of selenium in cervical cancer.

\section{Methods}

This case-control study included 20 subjects with cervical cancer and 20 healthy subjects. During the sample-processing, measurement of GPx activities in one sample failed. The subjects were women who were newly diagnosed with cervical cancer based on the clinical and histopathological findings, recruited consecutively from patients visited the gynecology outpatient clinic of Dr. Hasan Sadikin General Hospital from May to June 2013. The control group included matched healthy women without any malignancy and metabolic disorders, such as heart disease, kidney disorders, hypertension, or diabetes mellitus, based on the socioeconomical factors. A more detailed summary of the characteristics in both cervical cancer patients (age and Fédération Internationale de Gynécologie et d'Obstétrique/FIGO stage) and healthy control groups (age) are shown (Table 1 and 2).
Table 1 Characteristic, GPx-activity and Selenium Serum of Control Group

\begin{tabular}{cccc}
\hline No & $\begin{array}{c}\text { Control } \\
\text { group } \\
\text { patient's } \\
\text { age (YO) }\end{array}$ & $\begin{array}{c}\text { GPX-activity } \\
\text { ( } \mathbf{\text { Mmmol }} \text { (YDPH/ } \\
\text { min/L) }\end{array}$ & $\begin{array}{c}\text { Selenium } \\
\text { (ng/mL) }\end{array}$ \\
\hline 1 & 50 & 119 & 72.8 \\
2 & 47 & 165 & 82.1 \\
3 & 37 & 158 & 71.7 \\
4 & 30 & 162 & 67.2 \\
5 & 51 & 146 & 87.7 \\
6 & 46 & 192 & 79.8 \\
7 & 54 & 169 & 83.8 \\
8 & 35 & 175 & 77.6 \\
9 & 26 & 133 & 60.7 \\
10 & 33 & 161 & 51.4 \\
11 & 28 & 138 & 54.2 \\
12 & 32 & 119 & 86.6 \\
13 & 37 & 146 & 85.8 \\
14 & 45 & 147 & 73.6 \\
15 & 32 & 180 & 81.0 \\
16 & 27 & 128 & 96.8 \\
17 & 37 & N/A & 73.1 \\
18 & 47 & 130 & 80.0 \\
19 & 45 & 110 & 94.2 \\
20 & 32 & 153 & 77.0 \\
\hline & $40 \pm 8.8$ & $148.9 \pm 23$ & $77.05 \pm 12$ \\
Y0: years old & & \\
& & &
\end{tabular}

Blood samples were collected from both cervical cancer patients and healthy control group via antecubital vein puncture. All samples were then centrifuged to separate the $\mathrm{RBC}$ and serum. After centrifugation, the serum samples were frozen at $-80^{\circ} \mathrm{C}$ for subsequent analysis of total selenium concentration, GPx activity, and other standard blood parameters such as hemoglobin, leucocytes, thrombocytes, hematocrite, mean corpuscular volume, mean corpuscular hemoglobin, mean corpuscular hemoglobin concentration, glucose, activated partial thromboplastin time (aPTT), and prothrombin (PTT).

The study protocol was approved by the Ethics Committee of the Faculty of Medicine, Universitas Padjadjaran-Dr. Hasan Sadikin General Hospital, Bandung, Indonesia. All subjects were provided informed consent prior to participation. 
Table 2 Characteristics, GPx-activity, and
Selenium Serum of Patients with
Cervical Cancer

\begin{tabular}{ccccc}
\hline No & $\begin{array}{c}\text { Cervical } \\
\text { cancer } \\
\text { patient's } \\
\text { age (YO) }\end{array}$ & Staging & $\begin{array}{c}\text { GPX- } \\
\text { activity } \\
\text { (4mmol } \\
\text { NADPH/ } \\
\text { min/L) }\end{array}$ & $\begin{array}{c}\text { Selenium } \\
\text { (ng/mL) }\end{array}$ \\
\hline 1 & 50 & III B & 79 & 51.4 \\
2 & 47 & II B & 180 & 83.8 \\
3 & 37 & III B & 50 & 56.1 \\
4 & 30 & III B & 122 & 75.9 \\
5 & 51 & II A1 & 145 & 89.2 \\
6 & 46 & II B & 98 & 64.3 \\
7 & 54 & III A & 78 & 62.9 \\
8 & 35 & II B & 94 & 50.2 \\
9 & 26 & II B & 148 & 49.4 \\
10 & 33 & I B1 & 162 & 95.4 \\
11 & 28 & III B & 92 & 46.0 \\
12 & 32 & II B & 150 & 68.3 \\
13 & 37 & II B & 142 & 59.3 \\
14 & 45 & II B & 205 & 57.8 \\
15 & 32 & II A1 & 127 & 80.1 \\
16 & 27 & II B & 125 & 79.8 \\
17 & 37 & I B2 & N/A & 98.0 \\
18 & 47 & I B1 & 141 & 80.1 \\
19 & 45 & II B & 146 & 68.8 \\
20 & 32 & II A2 & 152 & 58.7 \\
\hline & $48.1 \pm 9.5$ & & $128.18 \pm 38$ & $67.24 \pm 15$ \\
\hline & & & &
\end{tabular}

YO: years old

The selenium concentration was calculated based on the fluorometric measurements at an excitation wave length of $378 \mathrm{~nm}$ and an emission wave length of $525 \mathrm{~nm}$ to determine the concentration of piazoselenol, which is produced by the reaction of selenite with 2,3-diamino naphtalene. ${ }^{7}$

The validity of the selenium analysis was confirmed by the measurement of a reference material (bovine liver, SRM 1577b, National Institute of Standards and Technology, USA).

The glutathione peroxidase activities were spectrophotometrically measured based on the decreasing rate of NADPH used in the reduction of glutathione, which was generated from oxidized glutathione through a reaction catalyzed by glutathione reductase. ${ }^{7}$ Hydrogen peroxide and reduced glutathione were used as substrates at $37^{\circ} \mathrm{C}$ in the presence of NADPH and glutathione reductase. The rate of NADPH oxidation at $340 \mathrm{~nm}$ was used as an index of hydrogen peroxide reduction.

Paired t-tests were used to compare the total selenium concentrations and GPx activities of the cervical cancer and control groups. A $p$ value of less than 0.05 was considered as statistically significant.

\section{Results}

The mean age of women with cervical cancer and healthy controls were $48.1 \pm 9.5$ years and $40 \pm 8.8$ years, respectively. The total selenium concentrations in the cancer group and control group are presented (Fig. 1a). The selenium concentration in the cancer group $(67.24 \pm 15$ $\mathrm{ng} / \mathrm{mL})$ was significantly lower $(\mathrm{p}=0.03)$ than that of the control group $(77.05 \pm 12 \mathrm{ng} / \mathrm{mL})$. In addition, the GPx activity of the cancer group (128.18 \pm 38 Ämmol NADPH/min/L) was significantly lower $(p=0.04)$ than that of the control group $(148.9 \pm 23$ Ämmol NADPH/ min/L) (Fig. 1b). In this study, the stages of patients with cervical cancer were FIGO stage I B1 (2 patients), I B2 (1 patient), II A1 (2 patients), II A2 (1 patient), II B (9 patients), III A (1 patient) and III B (4 patients). Subjects were then clustered into early and advanced groups with a cut of point between FIGO stage II A2 and II B. From the results of the multivariate analysis using Cox proportional hazard model, it was revealed that the FIGO staging of cervical cancer patients (early vs. advanced) was inversely correlated with the serum selenium concentration ( $p=0.027)$.

\section{Discussion}

Selenium is an antioxidant agent that can reduce the amount of hydrogen peroxides, lipid and phospholipid hydroperoxides via GPx; thereby dampening the propagation of free radicals and ROS. It is well established that the antioxidant defense system scavenges the free radicals directly or interferes with the generation of free radical mediated events inhibiting the neoplastic process. ${ }^{11}$

In this study, the concentration of serum selenium and GPx activities of subjects with cervical cancer were significantly lower than those of healthy subjects.

As an essential trace element, selenium has been shown to affect the function of 
a

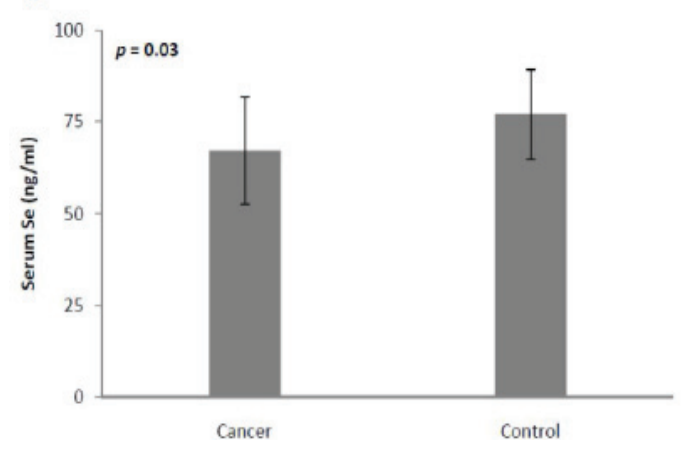

b

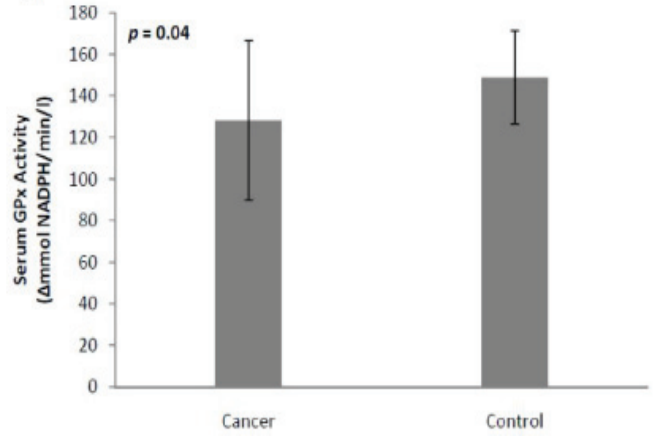

Fig. 1 The Mean of Selenium Serum Concentration, $67.24 \pm 15 \mathrm{ng} / \mathrm{mL}$ and $77.05 \pm 12$ $\mathrm{ng} / \mathrm{mL}(\mathrm{p}=0.03)(1 \mathrm{a})$ and GPx Activities, 128.18 $\pm 38 \Delta \mathrm{mmol} \mathrm{NADPH} / \mathrm{min} / \mathrm{L}$ and $148.9 \pm 23 \Delta \mathrm{mmol} N A D P H / \mathrm{min} / \mathrm{L}(\mathrm{p}=0.04)(1 \mathrm{~b})$ of Cervical Cancer Patients and Healthy Control Subjects, Respectively

selenoproteins by participating in the active site of antioxidant enzymes, such as GPx and thioredoxin reductase. Furthermore, selenium acts as anticancer agent through the plausible mechanisms like immune system stimulation and cell proliferation inhibition. ${ }^{12}$ Sustainable persuasive evidence indicates that selenium can certainly play an important role in cancer prevention. ${ }^{13}$

Study by Thompson et al..$^{14}$ in 2002 does not supportarelationship between serum selenium and invasive cervical cancer at the typical serum level in the United States, but an inverse association of selenium was observed among former smokers. Similar to above study, Brock and co-workers also did not find association between serum selenium level and the risk of insitu cervical cancer in Australia. Although the tendency of low serum concentration of selenium in those patients was observed, it did not reach significancy..$^{15}$ Both studies used neutron activation activity (NAA) with a value of selenium ranging from 67.5 to $185.0 \mathrm{ng} /$ $\mathrm{mL}$ and 27.6 to $<96.3$ microgr/L, respectively. On the other hand, our study found that low serum concentration of selenium and GPx activity in cervical cancer patients compared with control group. In agreement with our results, several studies showed that low serum concentration of selenium in uterine cervical carcinoma patients might be a contributing factor in the development of cervical cancer. ${ }^{5}$ This discrepancy might due to different of analytical methods and the number of subjects used in each study.
The prevention of tumor cell adhesion and migration is related to inhibition of tumor cell invasion into basement membrane. ${ }^{16}$ It was also documented that brief pre-exposure of HeLa cells to micromolar concentration of selenite, inorganic form of selenium, resulted in a dose-dependent decrease in the rate of their subsequent attachment to a solid matrix. ${ }^{17}$ Those findings also revealed a remarkable relationship between levels of trace elements vs. antioxidants enzymatic system, especially selenium vs GPx and the concentration of selenium is directly proportional to the GPx activity. Consistent with the above findings it is important to maintain a constant balance in serum trace elements like selenium in cancer patients which induces the enhancement of antioxidant enzymes.

Ueda and co-workers has reviewed the glutathion-S-transferase polymorphism which plays a role in conjugating of glutathion to the products of endogenous lipid peroxidation and also inactivating organic hydroperoxides via selenium-dependent GPx activity. ${ }^{18}$ The deletion of this gene promotes the development of cervical dysplasia through the involvement of oxidative stress and DNA adduct formation. ${ }^{19}$ In the following year, Krehl et al. ${ }^{20}$ stated that selenium deficiency is considered as a risk factor in cancer development. The protective effect of selenium might be mediated by specific selenoprotein, such as GPx. As their mouse model experiment result showed that adequate selenium supply provides protection against carcinogenesis, low selenium status 
highlights the risk of cancer development. ${ }^{20}$ Attention should be drawn to the several limitations of this study, including: (I) small patients sample size; (II) potential involvement of other microenvironment signaling pathways in the development of malignancy in cervical cancer; (III) indeed, we cannnot fully explain the mechanism of selenium in clinical phenomena. The phenomena of lowselenium concentration in cervical cancer patients, in this study, might be related to the

\section{References}

1. Jemal A, Bray F, Center MM, Ferlay J, Ward E, Forman D. Global cancer statistics. CA Cancer J Clin. 2011;61(2):69-90.

2. Klaunig JE, Wang Z, Pu X, Zhou S. Oxidative stress and oxidative damage in chemical carcinogenesis. Toxicol Appl Pharmacol. 2011;254(2):86-99.

3. Sedelnikova OA, Redon CE, Dickey JS, Nakamura AJ, Georgakilas AG, Bonner WM. Role of oxidatively induced DNA lesions in human pathogenesis. Mutat Res. 2010;704(1):152-9.

4. Subramanyam D, Subbaiah KV, Rajendra W, Lokanatha V. Serum selenium concentration and antioxidant activity in cervical cancer patients before and after treatment. Exp Oncol. 2013;35(2):97-100.

5. Kharb S, Sharma A, Kaushal V, Yadav S, Singh I. Low serum selenium concentration in patients with cervical cancer. Internet J Nutr Wellness. 2008;8(1):1-3.

6. Roman M, Jitaru P, Barbante C. Selenium biochemistry and its role for human health. Metallomics. 2014;6(1):25-54.

7. Abdulah A, Noerjasin H, Septiani L, Mutakin, Defi IR, Suradji EW, et al. Reduced selenium concentration in miscarriage incidence of Indonesian subjects. Biol Trace Elem Res. 2013;154(1):1-6.

8. Takata Y, Morris JS, King IB, Kristal AR, Lin DW, Peters U. Correlation between selenium concentrations and glutathione peroxidase activity in serum and human prostate tissue. Prostate. 2009;69(15):1635-42.

9. Wallace K, Kelsey K, Schned A, Morris J, Andrew A, Karagas M. Selenium and risk of bladder cancer: a population-based case-control study. Cancer Prev Res (Phila). 2009;2(1):70-3.

10. Takata Y, Kristal AR, King IB, Song X, Diamond $A M$, Foster $C B$, et al. Serum selenium, genetic complex mechanism, such as metabolisme of cancer cell itself, that remains to be elucidated. Understanding of selenium role both in normal and cancer cells might improve therapeutic strategies for patients with malignant diseases.

In conclusion, the serum concentration of selenium and GPX-activities were significantly lower in cervical cancer patients. This suggests that low serum concentration of selenium and GPx-activity might be contributing factors in the development of cervical cancer. variation in selenoenzymes, and risk of colorectal cancer: primary analysis from the Women's Health Initiative Observational Study and meta-analysis. Cancer Epidemiol Biomarkers Prev. 2011;20(9):1822-30.

11. Franco R, Cidlowski JA. Apoptosis and glutathione: beyond an antioxidant. Cell Death Differ. 2009;16(1):1303-14.

12. Labunskyy VM, Hatfield DL, Gladyshev VN. Selenoproteins: molecular pathways and physiological roles. Physiol Rev. 2014;94(3):739-77.

13. Combs GF Jr. Current evidence and research needs to support a health claim for selenium and cancer prevention. J Nutr. 2005;135(2):34347.

14. Thompson FE, Patterson BH, Weinstein SJ, McAdams M, Spate VL, Hamman RF, et al. Serum selenium and the risk of cervical cancer among women in the United States. Cancer Causes Control. 2002;13(6):517-26.

15. Brock KE, Gridley G, Morris JS, Willett WC. Serum selenium level in relation to in situ cervical cancer in Australia. J Natl Cancer Inst. 1991;83(4):292-3.

16. Kelley LC, Lohmer LL, Hagedorn EJ, Sherwood DR. Traversing the basement membrane in vivo: a diversity of strategies. J Cell Biol. 2014;204(3):291-302.

17. Zeng H, Combs GF Jr. Selenium as an anticancer nutrient: roles in cell proliferation and tumor cell invasion. J Nutr Biochem. 2008;19(1):1-7.

18. Ueda M, Hung YC, Terai Y, Saito J, Nunobiki O, Noda S, Ueki M. Glutathione-S-transferase and p53 polymorphisms in cervical carcinogenesis. Gynecol Oncol. 2005;96(3):736-40.

19. Kryston TB, Georgiev AB, Pissis P, Georgakilas AG. Role of oxidative stress and DNA damage in human carcinogenesis. Mutat Res. 
2011;711(1):193-201.

20. Krehl S, Loewinger M, Florian S, Kipp AP, Banning A, Wessjohann LA, et al. Glutathione peroxidase-2 and selenium decreased inflammation and tumors in a mouse model of inflammation-associated carcinogenesis whereas sulforaphane effects differed with selenium supply. Carcinogenesis. 2012;33(3):620-8. 